\title{
LITERACY DEVELOPMENT IN COURSE BOOKS FOR TEACHING ENGLISH IN THE SECOND CYCLE OF SLOVENIAN PRIMARY SCHOOL
}

\section{INTRODUCTION}

Literacy is a fundamental human right, and the foundation for lifelong learning (Unesco 2014). Its development generally starts early on, in the family, and continues throughout one's life, with its peak arriving in the early years of primary school. However, as Baker (2001) notes, exactly what constitutes literacy has been a topic of debate for several decades. Some definitions place an emphasis on reading, others on reading and writing, while still others include the socio-cultural, historical and political context of the learner (ibid.). In the present article, the main focus is on developing the reading skills of young learners of English.

In Slovenia, foreign language (FL) literacy development has not been dealt with in a sufficiently systematic and thorough way. This is reflected in the results of the SurveyLang final report, in which reading is the least-developed skill of Slovenian ninth graders, with 12\% failing to achieve A1 level (European Commission 2012: 42).

The present article focuses first on defining literacy skills within the Common European Framework of Reference for Languages (CEFR 2001), and on the development of literacy skills in English as the mother tongue (MT) and as an FL, as well as the challenge this poses to Slovenian learners. Since course books offer a hidden curriculum in FL teaching (Cunningsworth 1995), in the empirical part of the article, course books used for teaching English in the second cycle of Slovenian primary schools are analysed with regard to literacy development, particularly phonological, orthographic and orthoepic competences. In the conclusion, a more systematic approach is recommended in developing early literacy skills in English as a foreign language.

\section{DEFINING LITERACY WITHIN THE CEFR}

The Common European Framework of Reference for Languages (CEFR) divides all of the competences of the language user into general competences (including declarative knowledge, skills and know-how, existential competence and the ability to learn) and communicative language competences, which are further divided into linguistic competences, sociolinguistic competences and pragmatic competences (CEFR 2001).

* Author's address: Pedagoška fakulteta, Univerza v Ljubljani, Kardeljeva ploščad 16, 1000 Ljubljana, Slovenia. E-mail: mateja.dagarin@guest.arnes.si 
Linguistic competences refer to the "knowledge of, and ability to, use the formal resources from which well-formed, meaningful messages may be assembled and formulated" (ibid: 109). The subcomponents of linguistic competence are lexical, grammatical, semantic, phonological, orthographic and orthoepic (ibid.). Literacy is an essential part of communicative language competences, but is more clearly evident in the following linguistic competences (ibid.):

a) Phonological competence: knowledge of, and skill in, the perception and production of phonemes, the phonetic composition of words (syllables, the sequence of phonemes, word stress), sentence phonetics (e.g. sentence stress, rhythm) and phonetic reduction;

b) Orthographic competence: knowledge of, and skill in, the perception and production of the symbols with which written texts are composed (e.g. spelling, punctuation);

c) Orthoepic competence: the ability to produce correct pronunciation from the written form (e.g. reading aloud).

The following chapter presents the reading methods and approaches that contribute to the development of these three competences of language learners.

\section{DEVELOPING LITERACY IN ENGLISH AS THE MOTHER TONGUE AND AS A FOREIGN LANGUAGE}

In recent years, there has been an increased focus on the teaching of literacy skills to children learning English as a foreign language. Reading is gradually being recognised as a valuable source of input and, lately, literacy has not been viewed simply as the development of reading and writing skills, but as a complex process that includes listening and oral skills, as well. This is especially important when developing literacy with young language learners, where the focus is, initially, on developing listening and speaking skills. Young learners need to be exposed to the language in large amounts, and they should be given plenty of opportunities to play with the language. Early child literacy also needs to include activities for phonological and phonemic awareness (Griffith and Olson 1992; Share 1999 among others). Phonological awareness is the ability to recognise that words are made up of a variety of sound units. It encompasses skills such as recognising and using rhyme, breaking words into syllables, blending phonemes into syllables and words, identifying the beginning and ending sounds, and so on. Phonemic awareness is an aspect of phonological awareness dealing with the smallest unit of sound, i. e., the phoneme. It includes skills, such as the ability to recognise different sounds, to segment words into sounds, and to isolate, blend and manipulate sounds.

Phonological awareness has a primary role in reading acquisition. In fact, Share (1999) states that the main problem of reading acquisition is phonological recording, the ability to independently generate pronunciations for novel orthographic strings. According to Share (ibid.), the orthographic lexicon develops with increasing reading experience and "self-teaching". Goswami and Bryant (1990) likewise claim that onset 
and rime-level correspondences, in particular, are central to early reading development. Nijakowska (2010) summarises the findings of other experts dealing with teaching foreign languages to children with specific learning differences, stating that explicit phonological awareness training is necessary for children with dyslexia, who fail to sufficiently develop phonological awareness skills. In her research, Zrimšek (2003) also demonstrates the importance of phonemic awareness training in Slovenian as the mother tongue, as well as the influence of musical abilities on phonemic awareness, especially on aural discrimination. She suggests including activities for the development of phonemic awareness in preschool education, and in the first years of primary school education. Cunningham (1990), however, has established that merely focusing on phonemic awareness is not enough, and that tasks need to be meaningful, and to make sense to children, as well.

Children learning to read in their mother tongue are, more or less, fluent in speaking and understanding the language, and they can always depend on the oral language that they have acquired and build on that. The majority of the words they are learning to read are already present in their vocabularies. Children learning English as a FL, on the other hand, do not have the oral language to fall back on, and may be complete beginners in all four skills.

Another issue that causes problems for native speakers, and even more for FL learners, is the fact that English is a language with deep orthography (Skela, Sešek and Dagarin Fojkar 2009). English is an extreme example of a language in which morphological information is also coded in spelling, which creates inconsistency in graphemephoneme correspondences (Aro 2004). In English, the written script does not fully represent the phonemic structure of the spoken language. There are 26 letters in the alphabet and 44 phonemes, which can be written in as many as 2501 different combinations. Not only do graphemes have many different pronunciations, a given phoneme can be spelled with numerous different graphemes. Slovene, on the other hand, is a language of shallow orthography, where the grapheme-phoneme correspondences are regular and symmetrical, which makes the development of literacy skills much faster, compared to English orthography (Skela, Sešek and Dagarin Fojkar 2009).

Despite the differences in developing literacy in the mother tongue and a foreign language, there are some similarities, too. These need to be explored and exploited in teaching, in order to help children acquire the written form of the language. Lucas and Katz (1994) and Cummins (1991) state that there is a strong relationship between children's prior native language literacy, and their development of English literacy, and that we can simultaneously build on literacy skills in both the mother tongue and a foreign language. Children who can already read in their mother tongue can benefit from the application of transferable skills to FL reading.

Over the years, numerous approaches to teaching reading have appeared. They can be roughly divided into two main categories: part-centred (or bottom-up), and sociopsycholinguistic (also called meaning-emphasis or top-down) (Weaver 2002).

Socio-psycholinguistic approaches emphasise the construction of meaning from whole texts, and draw on children's schemata and personal experiences. One of the 
most well-known top-down approaches is the Whole Language Approach. It is a method of teaching reading by recognising words as whole pieces of language. Proponents of the whole language philosophy believe that language should not be broken down into letters and combinations of letters, and decoded. Instead, they believe that language is a complete system of making meaning, with words functioning in relation to each other in context (Moats 2007). The opponents of this method claim that one cannot (visually) remember as many words by heart as are used in everyday communication, and that it is much easier to remember the rules, and then apply them when reading new words.

Some of the main part-centred approaches are the phonics approach and the sight word or look-say approach. The sight word or look-say approach teaches children to recognise whole words, often using flashcards or other techniques, to help them quickly identify words. It is based on the belief that, if children can recognise approximately one hundred of the most frequently occurring words, they will be able to read about half of the words they encounter in most texts (Ediger 2001). The main rationale behind the phonics approach (also sometimes referred to as the skills approach) is that children will be able to read independently, if they can match the letters of the alphabet to their specific pronunciations. Therefore, children are explicitly taught sound-symbol patterns. The phonics approach has proved to be especially effective in teaching dyslectic children, due to the fact that developing phonological awareness is one of the main principles of the approach (see above). The Phono-Graphix approach is a step ahead of the phonics approach, its main principle being that letters do not make sounds, but rather represent sounds. It stems from what children already know (sounds) and teaches them the letters made by these sounds (McGuinness and McGuinness 1998).

The main criticisms of part-centred approaches are that the English language is too unpredictable, and that these approaches include practicing with stilted, unnatural sentences, which are usually taken out of context and written only for the sake of practising certain sounds. Nevertheless, new materials have recently been developed that try to bridge this gap, by including stories and activities that appeal to children (e.g. Sounds and Letters 2011).

Despite this constant battle of approaches, Ehri (2003: 10) determined, in a national UK study, that "systematic phonics instruction produced superior performance in reading compared to all types of unsystematic or no phonics instruction", and, as is reported in a 2006 UK national report (Rose 2006), a recent Australian report (National Inquiry into the Teaching of Literacy 2005) came to much the same conclusion.

Brown (2007) summarises the recent research, claiming that a combination of topdown and bottom-up processing (also called interactive reading) is a primary ingredient in successful teaching methodology, as both processes are important. Nuttall (1996: 17) agrees, saying that "in practice, a reader continually shifts from one focus to another, now adopting a top-down approach to predict probable meaning, then moving to the bottomup approach to check whether that is really what the writer says". Weaver (2002) also calls this a "whole-to-part-to-whole" approach, which is engaging and rich with meaning, but focuses systematically on specific textual features, so that children can draw their own conclusions about language and apply them to their reading and writing. Furthermore, 
different words will be read in different ways: some words will be decoded, while others will be sight-read, especially words that cannot be decoded (e.g., "the"). Hamayan (1994) points out that, because FL students represent a very diverse group of learners, they require a range of approaches. However, this is not usually the case in FL teaching. As Skela et al. (2009) observe, most teachers of English in Slovenia think that English orthography is too unpredictable to be taught systematically and, therefore, literacy in English as an FL is mostly developed through the Whole Language Approach, expecting learners to remember the spelling of countless words by heart.

Ultimately, the National Institute of Child Health and Human Development (2000) in the U.S. identified five essential components of effective reading programmes: phonemic awareness, phonics, reading fluency, vocabulary development and reading comprehension. There is no doubt nowadays that a balanced-literacy approach is the best, including different methods/approaches for different reading purposes and immersing the child in the language with plenty of books, meaningful reading activities and the like. Ediger (2001) suggests some other strategies to facilitate foreign language literacy development: to expose students to the many uses of print around them, to provide opportunities for children to read more extensively, to provide authentic purposes for reading and writing, to provide scaffolding for learning, to use oral skills to support reading and writing development and, finally, to focus students' attention on reading and writing strategies.

\section{THE STUDY}

\subsection{The Aim and Scope of the Study}

As Skela (2009: 247) puts it, "probably nothing influences the content and nature of institutionalised teaching and learning more than the textbooks". Course books depict changes taking place in FL methodology, authors' views on language learning, learning in general and social context, which Cunningsworth (1995) calls the "hidden curriculum" in FL teaching. Course books often replace syllabi in teaching, or are used on par with them. Tomlinson (2012: 144) notes that "given how important language-learning materials are, it is surprising how little attention they have received, until recently, in the literature on applied linguistics".

The analysis in the present article is a content-orientated, in-depth evaluation (facilitated by a checklist of key indicators) of course books used for teaching English in the second cycle of Slovenian primary schools, with regard to literacy development. Five accredited course books for each grade in the second triad of Slovenian primary schools were selected and analysed (a total of 15 course books ${ }^{1}$ ).

Since the final consensus on reading approaches is that an eclectic approach is best for acquiring literacy skills, both in English as the mother tongue and as a FL (see previous section), and since it is generally assumed that developing English literacy skills in Slovenia is based on top-down approaches (with the Whole Language Approach pre-

1 The complete list of the analysed course books can be found at the end of the article. 
vailing), the present article focuses on exploring the elements of bottom-up approaches in course books, including phonological awareness, and indirectly on the development of the competences defined in the CEFR as phonological, orthographic and orthoepic.

The study attempts to answer the following research questions (RQ):

RQ1. Does the course book explicitly demonstrate or illustrate sound-letter combinations and offer practice of such combinations?

RQ2. Does the course book include guided exercises to practise sounds, word or sentence stress, syllabication and intonation?

RQ3. Does the course book include rhymes (e.g., in rhyming songs/chants or poems)?

RQ4. Does the course book include sound games, texts or sentences with the same repeating sound, alliteration (e.g. tongue twisters), searching for words beginning/ending with the same sound/letter (e.g. I spy), and the like?

RQ5. Does the course book introduce the English alphabet?

In the following section, the data is presented for each course book and grade.

\subsection{Data Analysis}

\begin{tabular}{|l|c|c|l|l|c|}
\cline { 2 - 6 } \multicolumn{1}{l|}{} & RQ1 & RQ2 & \multicolumn{1}{|c|}{ RQ3 } & RQ4 & RQ5 \\
\hline Happy Street 1 & $\mathrm{X}$ & $\mathrm{X}$ & $\begin{array}{l}\sqrt{ } \text { (4 rhyming chants/ } \\
\text { songs })\end{array}$ & $\mathrm{X}$ & $\mathrm{X}$ \\
\hline Hi there 4! & $\mathrm{X}$ & $\mathrm{X}$ & $\begin{array}{l}\sqrt{ }(19 \text { rhyming chants/ } \\
\text { songs })\end{array}$ & $\begin{array}{l}\sqrt{ } \text { ( a story with a } \\
\text { repeating sound })\end{array}$ & $\sqrt{ }$ \\
\hline $\begin{array}{l}\text { New } \text { Chatterbox } \\
\text { 1 }\end{array}$ & $\mathrm{X}$ & $\mathrm{X}$ & $\begin{array}{l}\sqrt{ }(2 \text { rhyming chants/ } \\
\text { songs })\end{array}$ & $\sqrt{ }$ (tongue twisters) & $\sqrt{ }$ \\
\hline $\begin{array}{l}\text { Reach for the } \\
\text { Stars 4 }\end{array}$ & $\mathrm{X}$ & $\mathrm{X}$ & $\begin{array}{l}\sqrt{ }(9 \text { rhyming chants/ } \\
\text { songs })\end{array}$ & $\sqrt{ }$ (I spy game) & $\sqrt{ }$ \\
\hline
\end{tabular}

Table 1: Analysed course books - 4th grade

The results of the analysed course books for the 4th grade show that none of the books include (explicit) demonstrations or exercises to practise awareness of soundletter combinations. Similarly, none of the course books include exercises to practise sounds, stress or syllabication. However, some elements of phonological awareness are developed implicitly, through chants and songs that include rhymes. It is interesting to note the difference in the number of such rhymes: some course books include as few as two, whereas one book has as many as nineteen. The course books that have fewer rhyming chants/songs usually do not have abundant songs/chants in general. Interestingly, the course books written by Slovene authors feature significantly more rhyming 
songs/chants, compared to those written for the global market. As far as sound games are concerned, most accredited course books for the 4th grade include one or two such games, frequently an "I spy" game, which may cause problems for pupils because they need to look for the words with the initial alphabetic names, rather than the initial letter sounds of the word. Three out of five of the analysed course books mention the English alphabet, probably because the 4th grade is the first year of formal English instruction, and some pupils may not know those letters of the English alphabet that the Slovene alphabet does not have (Q, X, Y and W).

\begin{tabular}{|c|c|c|c|c|c|}
\hline & RQ1 & RQ2 & RQ3 & RQ4 & RQ5 \\
\hline Happy Street 2 & $\mathrm{X}$ & $\mathrm{X}$ & $\begin{array}{l}\sqrt{ }(4 \text { rhyming } \\
\text { chants/songs })\end{array}$ & $\sqrt{ }$ (I spy game) & $\sqrt{ }$ \\
\hline My Sails 2 & $\mathrm{X}$ & $\mathrm{X}$ & $\begin{array}{l}\sqrt{ }(23 \text { rhyming } \\
\text { chants/songs })\end{array}$ & $\begin{array}{l}\sqrt{ } \text { (words on a } \\
\text { letter) }\end{array}$ & $\sqrt{ }$ \\
\hline Hi there 5! & $\mathrm{X}$ & $\mathrm{X}$ & $\begin{array}{l}\sqrt{ }(6 \text { rhyming } \\
\text { chants/songs })\end{array}$ & $\mathrm{X}$ & $\sqrt{ }$ \\
\hline New Chatterbox 2 & $\mathrm{X}$ & $\mathrm{X}$ & $\begin{array}{l}\sqrt{ }(8 \text { rhyming } \\
\text { chants/songs })\end{array}$ & $\begin{array}{l}\sqrt{ } \text { (tongue } \\
\text { twisters) }\end{array}$ & $\mathrm{X}$ \\
\hline Reach for the Stars 5 & $X$ & $\mathrm{X}$ & $\begin{array}{l}\sqrt{ }(16 \text { rhyming } \\
\text { chants/songs) }\end{array}$ & $\begin{array}{l}\sqrt{ } \text { ( a part of } \\
\text { a story with } \\
\text { a repeating } \\
\text { sound) }\end{array}$ & $\mathrm{X}$ \\
\hline
\end{tabular}

Table 2: Analysed course books - 5th grade

The results of the analysed course books for the 5th grade are similar to the results of those for the 4th grade, in that none of the books include explicit demonstrations or exercises to practise sound-letter combinations or sounds, though they do include rhymes, which help pupils to remember some words with the same sounds. Again, the course books written by Slovene authors offer, by far, the greatest number of such chants and songs, even exceeding the quantity in the 4th grade, probably because more attention is devoted to the development of reading skills in the second year of learning. Some course books mention the English alphabet only in the second year of formal learning of English, which can be a little late, as pupils are required to use its letters from the 4th grade onwards. 


\begin{tabular}{|c|c|c|c|c|c|}
\hline & RQ1 & RQ2 & RQ3 & RQ4 & RQ5 \\
\hline $\begin{array}{l}\text { Messages } \\
1\end{array}$ & $\mathrm{X}$ & $\begin{array}{l}\sqrt{ } \text { (reading words with } \\
\text { the same sound, word } \\
\text { stress, pronunciation of } \\
\text { plural nouns, sentence } \\
\text { stress, intonation, read- } \\
\text { ing and matching words } \\
\text { with the same vowels) }\end{array}$ & $\begin{array}{l}\sqrt{ } \\
\text { (1 rhyming } \\
\text { poem) }\end{array}$ & $X$ & $\sqrt{ }$ \\
\hline My Sails 3 & $\mathrm{X}$ & $\begin{array}{l}\sqrt{ } \text { (finding rhyming pairs, } \\
\text { reading/classifying } \\
\text { words with the same/dif- } \\
\text { ferent sound) }\end{array}$ & $\begin{array}{l}\sqrt{ }(12 \text { rhyming } \\
\text { chants/songs })\end{array}$ & $\begin{array}{l}\sqrt{ }(\text { a story } \\
\text { with re- } \\
\text { peating } \\
\text { sound })\end{array}$ & $\sqrt{ }$ \\
\hline Project 1 & $\mathrm{X}$ & $\begin{array}{l}\sqrt{ } \text { (reading words with } \\
\text { the same/different } \\
\text { sound, matching sounds } \\
\text { to words, classifying let- } \\
\text { ters that make the same } \\
\text { sound, writing correct } \\
\text { sounds, finding rhyming } \\
\text { pairs, word stress, sen- } \\
\text { tence stress, intonation, } \\
\text { syllabication) }\end{array}$ & $\begin{array}{l}\sqrt{ }(7 \text { rhyming } \\
\text { chants/songs })\end{array}$ & $\begin{array}{l}\sqrt{ } \text { (tongue } \\
\text { twisters) }\end{array}$ & $\begin{array}{l}\sqrt{ } \\
\text { (phonetic } \\
\text { alphabet) }\end{array}$ \\
\hline $\begin{array}{l}\text { Touch- } \\
\text { stone } 6\end{array}$ & $\sqrt{ }$ & $\begin{array}{l}\sqrt{ } \text { (reading words with } \\
\text { the same/different } \\
\text { sound, pronunciation of } \\
\text { plural nouns, classifying } \\
\text { words with the same/ } \\
\text { different sound, writing } \\
\text { the missing letters, silent } \\
\text { letters) }\end{array}$ & $\begin{array}{l}\sqrt{ }(19 \text { rhyming } \\
\text { chants/songs) }\end{array}$ & $\mathrm{X}$ & $\sqrt{ }$ \\
\hline $\begin{array}{l}\text { Reach for } \\
\text { the Stars } 6\end{array}$ & $\mathrm{X}$ & $\begin{array}{l}\sqrt{ } \text { (reading words with } \\
\text { the same/different } \\
\text { sound; classifying words } \\
\text { with the same sound, } \\
\text { matching the same vow- } \\
\text { els) }\end{array}$ & $\begin{array}{l}\sqrt{ }(8 \text { rhyming } \\
\text { chants/songs })\end{array}$ & $\mathrm{X}$ & $\begin{array}{l}\sqrt{ } \text { (vowels } \\
\text { of the } \\
\text { alphabet) }\end{array}$ \\
\hline
\end{tabular}

Table 3: Analysed course books - 6th grade

The analysis summarised in Table 3 reveals a different picture in the 6th grade. All of the course books encompass exercises for practising the different sounds of the English language, mostly in the form of listening to and reading words that have a certain sound, and matching or classifying words with the same sound. Almost all of the course books include exercises where pupils have to distinguish between two similar sounds (e.g., long vs. short vowels). Most of the course books have one such exercise per unit, 
with one exception, Touchstone 6, which has at least two pages of such practice per unit. Touchstone 6 is also the only course book that illustrates sound-letter combinations (letters in a word that make a certain sound are written with a different colour). There are fewer rhyming songs in the course books for the 6th grade, compared to the first two grades of the second cycle, but those included are longer and linguistically more demanding. All of the course books include the alphabet, which represents revision for most pupils at this stage. One course book introduces the English phonetic alphabet, which can help learners with reading new words. This book does not, however, offer a systematic approach to learning about sound-letter combinations.

\section{DISCUSSION}

The analysis has shown that only one of the fifteen analysed course books for teaching English in the second cycle of primary school explicitly illustrates sound-letter combinations, although almost all of them implicitly include some elements of bottomup approaches to reading, mostly in the form of rhyming songs/chants, the introduction of the alphabet and, only in the 6th grade, the limited use of exercises aimed at helping pupils develop orthographic reading skills.

Nevertheless, the mere presence of these implicit elements (e.g. rhyming songs and chants) in the course books does not mean that they are used efficiently, for the purpose of learning literacy. It depends on the teacher and his/her way of using them, to make pupils more aware of the matching sounds and spelling. Slovene teachers of English generally use songs, games or tongue twisters for practising listening/speaking skills, and not for developing reading skills, which could be done with a more explicit focus on the rhyming, or repeated sounds and their spelling.

Regarding the learning of the alphabet, which is included in the course books at all levels of learning English in the second cycle of primary schools, it needs to be stressed that learning the alphabet per se may actually interfere with children trying to learn the sound system, because letter names are not predictive of their sounds. The alphabet should be used only for introducing those English letters to the students that are not present in the Slovene alphabet, and to practise their writing.

The analysis indicates that the course books do not deal systematically with teaching reading and writing skills, and do not help pupils become more aware of soundletter combinations. Pupils are left to their own devices to decode the unpredictable and inconsistent grapheme-phoneme correlations, and some of them struggle with English reading and writing throughout their entire primary schooling.

\section{CONCLUSION}

Literacy in a FL should be developed gradually, with the incorporation of all four linguistic skills, and exposure to plenty of varied and motivating reading materials and challenging activities, most particularly with the inclusion of both top-down and bottom-up reading approaches. 
The analysis of the accredited course books for teaching English in the second cycle of primary school has shown that some exercises are included to practise the different sounds of the language, particularly through singing rhyming songs and, in the 6th grade, listening to and reading words with the same sounds, but there is no systematic explanation of which sounds are represented by which letters. Teachers can, of course, include such sound-letter awareness activities in their lessons, especially with the sounds that pupils are struggling with. They can expose pupils to texts with the same repeated sound, and let pupils guess which sound is repeated and how it can be written down. Similarly, they can ask pupils to think of other words with the same sound, or let them write their own rhymes or stories featuring that sound (see Skela 2002 and Dagarin Fojkar et al. 2011 for more of such activities). Through such activities, pupils focus their attention on more systematic reading and writing strategies, enabling them, with the aid of interesting reading materials and authentic purposes for reading, to become fluent and independent readers in English.

\section{References}

ARO, Mikko (2004) Learning to read. The effect of orthography. Unpublished dissertation. Jyväskylä: University of Jyväskylä.

BAKER, Colin (2001) Foundations of bilingual education and bilingualism ( $\left.{ }^{\text {rd }} \mathrm{ed}.\right)$. Clevedon: Multilingual Matters.

BROWN, H. Douglas (2007) Teaching by Principles. An Interactive Approach to Language Pedagogy ( $3^{\text {rd }}$ ed.). White Plains, NY: Pearson Education ESL.

Common European Framework of Reference for Languages: Learning, Teaching, Assessment (2001). Cambridge: Cambridge University Press.

CUMMINS, Jim (1991) "Interdependence of first- and second-language proficiency in bilingual children." In: E. Bialystok (ed.), Language processing in bilingual children. New York, NY: Cambridge University Press, 70-89.

CUNNINGHAM, Anne Elisabeth (1990) "Explicit Versus Implicit Instruction in Phonemic Awareness." Journal of Experimental Child Psychology 50, 429-444.

CUNNINGSWORTH, Alan (1995) Choosing your Coursebook. Oxford: Heinemann.

DAGARIN FOJKAR, Mateja/Urška SEŠEK/Janez SKELA (2011) Sounds and Letters. Delovni zvezek za razvijanje opismenjevanja $v$ angleščini kot tujem jeziku. Ljubljana: Tangram.

DAGARIN FOJKAR, Mateja/Urška SEŠEK/Janez SKELA (2011) Sounds and Letters. Priročnik $k$ delovnemu zvezku za razvijanje opismenjevanja $v$ angleščini kot tujem jeziku. Ljubljana: Tangram.

EDIGER, Anne (2001) "Teaching Children Literacy Skills in a Second Language.” In: M. Celce-Murcia (ed.), Teaching English as a Second or Foreign Language (3 ${ }^{\text {rd }}$ ed.). London: Heinle \& Heinle Thomson Learning, 153-169.

EHRI, Linnea C. (2003) Systematic Phonics Instruction: Findings of the National Reading Panel. Paper presented at the DfES seminar on phonics on 17 March 2003 in London. 
EUROPEAN COMMISSION (2012) First European Survey on Language Competences: Final Report. Brussels: European Commission. 20 May 2014. http://www. surveylang.org/.

GOSWAMI, Usha/Peter BRYANT (1990) Phonological skills and learning to read. Exeter: Erlbaum.

GRIFFITH, Priscilla/Mary W. OLSON (1992) "Phonemic Awareness Helps Beginning Readers Break the Code." Reading Teacher 45/7, 516-523.

HAMAYAN, Else (1994) "Language development of low-literacy students." In: F. Genesee (ed.), Educating second language children. Cambridge: Cambridge University Press, 278-300.

LUCAS, Tamara/Anne KATZ (1994) "Reframing the Debate: The Roles of Native Languages in English-Only Programs for Language Minority Students." TESOL Quarterly 28/3, 537-561.

MCGUINNESS, Carmen/Geoffrey MCGUINNESS (1998) Reading Reflex: The foolproof phonographix method for teaching your child to read. New York: The Free Press.

MOATS, Louisa (2007) Whole-Language High Jinx. How to Tell When 'ScientificallyBased Reading Instruction' Isn't. Washington, DC: Thomas B. Fordham Foundation.

NATIONAL INQUIRY INTO THE TEACHING OF LITERACY (2005) Teaching Reading: Report and Recommendations. Commonwealth of Australia: Australian Government, Department of Education, Science and Training.

NATIONAL INSTITUTE OF CHILD HEALTH AND HUMAN DEVELOPMENT (2000) Report of the National Reading Panel. Teaching Children to Read: An Evidence-based Assessment of the Scientific Research Literature on Reading and Its Implications for Reading Instruction: Reports of the Subgroups (NIH Publication No. 00-4754). Washington, DC: U.S. Government Printing Office. 30 May 2014. http://www.nichd.nih.gov/publications/pubs/nrp/Pages/smallbook.aspx.

NIJAKOWSKA, Joanna (2010) Dyslexia in the Foreign Language Classroom. Bristol: Multilingual Matters.

NUTTALL, Christine (1996) Teaching Reading Skills in a Foreign Language ( $\left.2^{\text {nd }} e d.\right)$. Oxford: Heinemann.

ROSE, Jim (2006) Independent review of the teaching of early reading. Final report. 30 May 2014. http://webarchive.nationalarchives.gov.uk/20100526143644/http:/ standards.dcsf.gov.uk/phonics/report.pdf.

SHARE, David L. (1999) "Phonological Recoding and Orthographic Learning: A Direct Test of the Self-Teaching Hypothesis." Journal of Experimental Child Psychology $72,95-129$.

SKELA, Janez (2002) "Multi-literacy: literacy acquisition, (creative) reading and writing in a foreign and/or second language." In: V. Sollars (ed.), Issues in multi-literacy. Strasbourg: Council of Europe, 11-53.

SKELA, Janez (2009) “Tujezikovna učna gradiva za pouk v otroštvu.” In: K. Pižorn (ed.), Učenje in poučevanje dodatnih jezikov v otroštvu. Ljubljana: Zavod Republike Slovenije za šolstvo, 246-289. 
SKELA, Janez/Urška SEŠEK/Mateja DAGARIN FOJKAR (2009) “Opismenjevanje v tujem/drugem jeziku na zgodnji stopnji." In: K. Pižorn (ed.), Učenje in poučevanje dodatnih jezikov v otroštvu. Ljubljana: Zavod Republike Slovenije za šolstvo, 220-245.

TOMLINSON, Brian (2012) "Materials development for language learning and teaching." Language Teaching 45/2, 143-179.

UNESCO, Education building blocks - literacy. 19 September 2014. http://www.unesco.org/new/en/education/themes/education-building-blocks/literacy/.

WEAVER, Constance (2002) Reading Process and Practice (3 ${ }^{\text {rd }}$ ed.). Portsmouth: Heinemann.

ZRIMŠEK, Nataša (2003) Začetno opismenjevanje: Pismenost v predšolski dobi in prvem razredu devetletne osnovne šole. Ljubljana: Univerza v Ljubljani, Pedagoška fakulteta.

\section{List of Course Books Analysed}

$4^{\text {th }}$ grade:

MAIDMENT, Stella/Lorena ROBERTS (2010) Happy Street 1 (New Edition). Oxford: Oxford University Press, Mladinska knjiga.

MARANGON, Claudio/Cristina RICHIERI (2006) Hi there! 4. Ljubljana: Rokus.

JESENIK, Nevenka/Janez SKELA/Viljenka ŠAVLI (2011) My Sails 1 New. Maribor: Obzorja.

STRANGE, Derek (2006) New Chatterbox 1. Oxford: Oxford University Press, Mladinska knjiga.

NOVAK, Magdalena/Jožica NUČ (2003) Reach For The Stars 4. Ljubljana: DZS.

\section{$5^{\text {th }}$ grade:}

MAIDMENT Stella/Lorena ROBERTS (2012) Happy Street 2 (New Edition). Oxford: Oxford University Press, Mladinska knjiga.

MARANGON, Claudio/Cristina RICHIERI (2006) Hi there! 5. Ljubljana: Rokus.

JESENIK, Nevenka/Janez SKELA/Viljenka ŠAVLI (2003) My Sails 2. Maribor: Obzorja. STRANGE, Derek (2010) New Chatterbox 2. Oxford: Oxford University Press, Mladinska knjiga.

NOVAK, Magdalena/Jožica NUČ (2004) Reach For The Stars 5. Ljubljana: DZS.

\section{$6^{\text {th }}$ grade:}

GOODEY, Diana/Noel GOODEY (2005) Messages 1. Ljubljana: Rokus.

JESENIK, Nevenka/Viljenka ŠAVLI (2005) My Sails 3. Maribor: Obzorja.

HUTCHINSON, Tom (2011) Project 1 (Third Edition). Oxford: Oxford University Press, Mladinska knjiga.

MIHELAČ, Bojana/Danica Š. NOVOSEL (2006) Reach For The Stars 6. Ljubljana: DZS.

SKELA, Janez/Alenka GVARDJANČIČ/Dunja MARGUČ (2009) Touchstone 6. Maribor: Obzorja. 


\section{Abstract \\ LITERACY DEVELOPMENT IN COURSE BOOKS FOR TEACHING ENGLISH IN THE SECOND CYCLE OF SLOVENIAN PRIMARY SCHOOL}

In recent years, there has been an increased focus on the teaching of reading to children, and the development of their literacy skills in their mother tongue and foreign languages.

The theoretical part of the article introduces literacy, and its role within the Common European Framework of Reference for Languages. Literacy is part of the linguistic competences (particularly phonological, orthographic and orthoepic competences) that need to be acquired for successful communication. Unlike Slovene, English is a language with deep orthography, therefore, the development of literacy skills in English poses a considerable challenge to Slovenian learners.

In the empirical part of the article, course books used for teaching English in the second cycle of Slovenian primary schools have been analysed with regard to literacy development, especially phonological, orthographic and orthoepic competences. This includes activities for developing orthographic reading skills, phonological and phonemic awareness, and the like. The research has shown that this area is approached to a greater or lesser extent in course books, and that literacy skills are mostly developed in an unprincipled way, without any systematic planning. Finally, a more systematic approach is recommended in developing early literacy skills in English as a foreign language.

Keywords: literacy, orthographic and orthoepic competences, phonics, young foreign language learners, course books.

\section{Povzetek \\ RAZVIJANJE OPISMENJEVANJA V UČBENIKIH ZA UČENJE ANGLEŠČINE V DRUGEM TRILETJU SLOVENSKE OSNOVNE ŠOLE}

Poučevanje branja ter razvijanje opismenjevanja v maternem in v tujih jezikih je v zadnjih letih bolj poudarjeno kot nekdaj.

V teoretičnem delu članka je tako predstavljena pismenost in njena vloga v Skupnem evropskem jezikovnem okviru. Pismenost je del jezikovnih zmožnosti (še posebej fonološke, pravopisne in pravorečne zmožnosti), ki jih moramo usvojiti za uspešno sporazumevanje. Angleščina je za razliko od slovenščine jezik z zapleteno ortografijo, zato razvijanje opismenjevanja $v$ angleščini slovenskim učencem pogosto povzroča težave.

V empiričnem delu članka je predstavljena analiza učbenikov za učenje angleščine $\mathrm{v}$ drugem obdobju osnovne šole $\mathrm{z}$ vidika razvijanja opismenjevanja, s poudarkom na analizi fonološke, pravopisne in pravorečne zmožnosti. Raziskava med drugim vključuje analizo aktivnosti za razvijanje ortografskih/pravopisnih bralnih spretnosti ter fonološkega in fonemičnega uzaveščanja. Raziskava je pokazala, da se to področje v 
učbenikih ne razvija $\mathrm{v}$ enaki meri in da opismenjevanje $\mathrm{v}$ tujem jeziku večinoma poteka nenačrtovano in nesistematično. $V$ zaključku članka je podan predlog za bolj sistematičen pristop k razvijanju opismenjevanja $\mathrm{v}$ angleščini kot tujem jeziku.

Ključne besede: pismenost, pravopisna in pravorečna zmožnost, fonična metoda, mlajši učenci tujega jezika, učbeniki. 